\title{
Relative Salinity Tolerance of Intermountain Western United States Native Herbaceous Perennials
}

\author{
Nickolee Zollinger ${ }^{1}$ \\ Department of Horticulture, Iowa State University, Ames, IA 50011
}

Richard Koenig

Department of Crop and Soil Sciences, Washington State University, Pullman, WA 99164

Teresa Cerny-Koenig ${ }^{2}$

Department of Horticulture and Landscape Architecture, Washington State University, P.O. Box 646414, Pullman, WA 99164

\section{Roger Kjelgren \\ Department of Plants, Soils, and Biometeorology, Utah State University, Logan, UT 84332-4820}

Additional index words. calcium, sodium, chloride, gas exchange, visual quality, media salinity

Abstract. The authors investigated salinity tolerance of four intermountain western United States native (Penstemon palmeri, Mirabilis multiflora, Geranium viscosissimum, and Eriogonum jamesii) and four common (Echinacea purpurea, Lavandula angustifolia, Leucanthemum $\times$ superbum 'Alaska', and $\times$ Penstemon mexicali 'Red Rocks') ornamental herbaceous perennials. Each was irrigated with a solution containing $2 \mathrm{CaCl}_{2}: 1 \mathrm{NaCl}$ (M ratio) at salinity levels of 0 (control), 1000, 3000, and $5000 \mathrm{mg} \cdot \mathrm{L}^{-1}$ during two 8-week experiments. They measured weekly visual quality and gas exchange and final shoot and root dry weights. Mirabilis multiflora, $L$. $\times$ superbum, and $L$. angustifolia maintained high visual quality and $100 \%$ survival across salinity levels. However, dry weights for $L$. xsuperbum decreased at salt levels $\geq 3000 \mathrm{mg} \cdot \mathrm{L}^{-1}$ in both experiments and for $L$. angustifolia in one experiment. Mortality rates of $12 \%$ to $100 \%$ were observed for the remaining five species irrigated with 3000 and $5000-\mathbf{m g} \cdot L^{-1}$ solutions. Visual quality of $P$. palmeri, G. viscosissimum, and $E$. purpurea varied with time of year the experiment was conducted, with low visual quality associated with high temperatures and light intensities, whereas dry matter and gas exchange responses to salinity were similar between the two experiments. Penstemon $\times$ mexicali and $E$. jamesii exhibited high mortality, low visual quality, and low gas exchange in the case of $E$. jamesii at high salinity treatments regardless of when experiments were conducted. Based on visual quality responses, $M$. multiflora, $L$. $\times$ superbum, and $L$. angustifolia are relatively more salt tolerant, and $\boldsymbol{P}$. $\times$ mexicali and $E$. jamesii are relatively more intolerant, than the three other species. Penstemon palmeri, G. viscosissimum, and E. purpurea exhibited intermediate tolerance to salinity with acceptable quality during periods of cool temperatures and lower light intensities.

As the demand for and cost of potable water has increased, recycled and secondary water have become attractive alternatives for landscape irrigation (Kjelgren et al., 2000). However, the use of recycled and secondary water in landscape applications is limited because salinity levels are often higher than

\footnotetext{
Received for publication 6 Dec. 2006. Accepted for publication 22 Feb. 2007

Technical contribution no. 7722 of the Utah Agricultural Exp. Sta.

This paper is part of a thesis written by the senior author in partial fulfillment of a master's degree requirement.

${ }^{1}$ Former graduate research assistant.

${ }^{2}$ To whom reprint requests should be addressed; e-mail tckoenig@wsu.edu
}

in primary or culinary sources. Salinity levels for some recycled water may be as low as $2 \mathrm{dS} \cdot \mathrm{m}^{-1}$ (Lindsey et al., 1998), whereas salinity levels for secondary water can exceed $5 \mathrm{dS} \cdot \mathrm{m}^{-1}$ (James and Jurinak, 1986).

Relatively little research has been conducted to assess the soil salinity tolerance of ornamental plants. However, for some crop plants, damage can occur with irrigation salinity levels more than 1.0 to $2.0 \mathrm{dS} \cdot \mathrm{m}^{-1}$ (Maas and Grattan, 1999). Salinity stress in soil-based systems is a result of both ion toxicities and the combined osmotic effects of salts accumulating in the soil and matric effects of soil drying (Bernstein, 1975; Glenn and Brown, 1998), and thus can produce different symptoms than those seen in hydroponic culture. Typical plant responses to soil salinity include reduced shoot and root growth rates (Munns, 2002), reduced leaf or shoot number (Munns, 2002), declines in stomatal conductance $\left(g_{\mathrm{S}}\right)$ and photosynthesis rates (Kerstiens et al., 2002; Rivelli et al., 2002; Wang and Nii, 2000), and damage or death of leaves (Munns, 2002). Because many of the common responses to salinity decrease the visual quality of the plant, salinity may limit the use of specific plants in greenhouse or landscape settings where saline irrigation water is used.

Plant responses to salinity, particularly visual responses, are typically more severe when leaves are exposed directly to salinity (Simini and Leone, 1986; Wu et al., 2001). Thus, although salt spray studies (Deeter, 2001; Wu et al., 2001) may be valid for a general comparison of species tolerance to salinity, the results may not be readily extrapolated to soil-based systems in which irrigation water does not come in contact with leaves.

A limited number of commonly grown herbaceous perennials have native distributions in saline environments and are thought to have some tolerance to salinity. For example, Leucanthemum $\times$ superbum grows along seashores (Phillips and Burrell, 1993), and Lavandula species are frequently found in harsh Mediterranean climates where they are exposed to sea spray (Upson and Andrews, 2004). These plants are well suited for use in landscapes where saline irrigation water is used. However, to maintain high visual appeal and ecological diversity within these landscapes, more salt-tolerant selections need to be identified. Because a large proportion of the soils in the intermountain western United States (IMW; the biogeographical region between the Sierra Nevada and Rocky Mountain ranges) are saline, this region may be a source of potentially salttolerant herbaceous perennials (Mee et al., 2003).

Quantitative knowledge of the salinity tolerance of specific herbaceous perennials is important if these plants are to have a place in landscapes irrigated with saline water. Visual quality is an important factor in screening for salt tolerance of herbaceous perennials for ornamental landscapes. Because plants respond differently to salinity, visual quality may or may not be related to biomass production and photosynthetic response. The primary objective of this study was to evaluate the relative salinity tolerance of four commonly grown and four IMW native ornamental herbaceous perennials based primarily on visual quality, survival, and plant biomass. A secondary objective was to assess the effect of saline irrigation on gas exchange properties of these species.

\section{Materials and Methods}

Experimental design. The study was conducted at the Utah State University Research Greenhouses (North Logan, Utah; lat., $41^{\circ} 45^{\prime} \mathrm{N}$; long., $\left.111^{\circ} 48^{\prime} \mathrm{W}\right)$. For each of the eight species used in the study, experiments were performed at two of the four time 
periods: Spring 2003 (9 May-3 July), Spring 2004 (10 Apr.-2 June), Summer 2004 (18 June-12 Aug.), or Fall 2004 (22 Oct.17 Dec.). The experimental design was a randomized complete block with two blocks and four replicates within each block. Individual species were treated as blocking units to minimize the effects of shading from plants of different sizes. Treatments consisted of four irrigations [tap water control, $0 \mathrm{mg} \cdot \mathrm{L}^{-1}\left(0.3 \mathrm{dS} \cdot \mathrm{m}^{-1}\right.$ measured salinity) or a 2:1 (molar ratio) mixture of $\mathrm{CaCl}_{2}$ and $\mathrm{NaCl}$ at 1000,3000 , or $5000 \mathrm{mg} \cdot \mathrm{L}^{-1}$ ] simulating increasing levels of salinity. The 1000-, $3000-$, and $5000-\mathrm{mg} \cdot \mathrm{L}^{-1}$ salinity treatments had average measured electrical conductivities (ECs) of 1.9, 5.0, and $8.1 \mathrm{dS} \cdot \mathrm{m}^{-1}$ respectively. Treatments were applied to each of the following eight plant species: Penstemon palmeri (Palmer penstemon), Mirabilis multiflora (desert four o'clock), Geranium viscosissimum (sticky geranium), Eriogonum jamesii (James buckwheat), Echinacea purpurea (purple coneflower), Lavandula angustifolia (English lavender), L. ×superbum 'Alaska' (Alaska Shasta daisy), and Penstemon $\times$ mexicali 'Red Rocks' (red rocks penstemon). Penstemon palmeri, M. multiflora, G. viscosissimum, and E. jamesii are native to the IMW, whereas the other four species are commonly available in the nursery industry.

Environmental conditions. Greenhouse temperatures were set at $16{ }^{\circ} \mathrm{C}$ night $/ 27{ }^{\circ} \mathrm{C}$ day for all experiments, and minimum and maximum air temperatures were recorded daily and averaged for the study (Table 1). Supplemental lighting (high-pressure sodium, 16-h photoperiod) was used during the Fall 2004 experiment when ambient light levels were low. Otherwise, ambient light levels were used. The daily integral of photosynthetically active radiation was measured during 2004 and 2005 (Table 1) using a light bar and hand-held datalogger (Apogee, Logan, Utah).

Plant material and media. Uniform plugs in 32-cell trays (328-mL cell volume) were obtained from either a commercial nursery

Table 1. Species, average greenhouse daily light integral (DLI), and average minimum and maximum air temperature for the four experiment periods.

\begin{tabular}{|c|c|c|c|}
\hline Season & Species used & $\begin{array}{c}\text { DLI } \\
\left(\mathrm{mol} \cdot \mathrm{m}^{-2} \cdot \mathrm{d}^{-1}\right)\end{array}$ & $\begin{array}{l}\text { Average air } \\
\text { temperature } \\
\left(\mathrm{min} / \mathrm{max},{ }^{\circ} \mathrm{C}\right)\end{array}$ \\
\hline Spring 2003 (9 May to 3 July) & $\begin{array}{l}\text { Echinacea purpurea } \\
\text { Eriogonum jamesii } \\
\text { Lavandula angustifolia } \\
\text { Penstemon palmeri }\end{array}$ & Not recorded & $15 / 28$ \\
\hline Spring 2004 (10 Apr. to 2 June) & $\begin{array}{l}\text { E. jamesii } \\
\text { L. angustifolia } \\
\text { Leucanthemum } \times \text { superbum } \\
\text { E. purpurea }\end{array}$ & 13.88 & $16 / 28$ \\
\hline Summer 2004 (18 June to 12 Aug.) & $\begin{array}{l}\text { Geranium viscosissimum } \\
\text { Mirabilis multiflora } \\
\text { P. ×mexicali } \\
\text { P. palmeri }\end{array}$ & 17.98 & $15 / 33$ \\
\hline Fall 2004 (22 Oct. to 17 Dec.) & $\begin{array}{l}\text { G. viscosissimum } \\
\text { L. ×superbum } \\
\text { M. multiflora } \\
P . \times \text { mexicali }\end{array}$ & 15.54 & $12 / 29$ \\
\hline
\end{tabular}

DLI, daily light integral. or the Utah State University horticulture research program and transplanted into 3.8$\mathrm{L}$ pots containing 5 parts composted bark $(3 \mathrm{~mm}): 4$ parts screened pumice $(3 \mathrm{~mm}): 1$ part peat (by volume). In Spring 2003, $P$. palmeri plugs in 72 -cell trays $(64-\mathrm{mL}$ cell volume) were transplanted, and in Summer 2004, G. viscosissimum growing in $10-\mathrm{cm}$ square pots (1049-mL volume) were transplanted because no other sizes were commercially available at these times. Each plant was watered regularly with tap water until established, and top dressed with $18 \mathrm{~g}$ slow-release fertilizer $(14 \mathrm{~N}-4.2 \mathrm{P}-11.6 \mathrm{~K}) 1$ week before treatments began.

Salinity treatments. During 2003, individual plants were watered with treatment solutions as needed by visual inspection and pot weight. Starting in 2004, a 12-cm-long soil moisture probe (HydroSense; Campbell Scientific, Logan, Utah) was used daily to determine when individual plants needed watering was discontinued on three plants of each species until visual signs of wilting were observed. During this time, stomatal closure for each plant was measured daily using a steady state porometer (Li-1600; LI-COR, Lincoln, Nebr.), and media moisture readings were taken within the root zone of each pot. Mean stomatal closure was correlated with the mean moisture reading for each plant, and the moisture content at which the stomata began to close was determined for each species as the threshold for watering. For all experiments in 2004, media moisture was monitored daily, and plants were watered if media moisture fell below the threshold level. Because readings from the soil moisture probe are affected by media salinity, readings for salt-treated media were adjusted to reflect the true media moisture content. Adjustments were determined by relating moisture probe readings from unplanted pots watered with the control and saline solutions to gravimetric soil water content. A leaching fraction of $\approx 20 \%$ was used each time salt solutions were applied to minimize salt accuwater. Before the 2004 experiments began, mulation in the media. Watering was discontinued if plants died.

Visual quality and dry weight. Visual quality of each plant was assessed weekly and ranked on a scale of 1 to 5 based on the amount of burn, discoloration, and wilt plants exhibited. Gradations in the rating scale were as follows: For burn, 1, more than $50 \%$ of the leaf area burned; $2,25 \%$ to $50 \%$ of the leaf area burned; $3,5 \%$ to $24 \%$ of the leaf area burned; 4 , less than $5 \%$ of the leaf area burned, with burn primarily restricted to leaf tips; 5, no leaf burn. For discoloration, 1, more than $50 \%$ of the leaf area discolored (yellowed); $2,25 \%$ to $50 \%$ of the leaf area discolored; $3,5 \%$ to $24 \%$ of the leaf area discolored; 4 , less than $5 \%$ of the leaf area discolored; 5, no discoloration. For wilt, 1 , more than $65 \%$ of the plant was wilted; 2 , $35 \%$ to $65 \%$ of the plant was wilted; $3,5 \%$ to $34 \%$ of the plant was wilted; 4 , less than $5 \%$ of the plant was wilted; 5 , plant fully turgid. Dead plants were given a quality rating of 0 . Individual ratings for burn, discoloration, and wilt were averaged weekly to give an overall visual quality rating. Other visual symptoms were also noted if observed. At the end of each experiment, plants were harvested, medium was washed from the roots, and shoots and roots were separated. Plant tissue was dried at $70{ }^{\circ} \mathrm{C}$ for $48 \mathrm{~h}$, and dry weights were recorded.

Gas exchange. Photosynthesis $\left(\mathrm{P}_{\mathrm{n}}\right)$ and $g_{\mathrm{s}}$ was monitored weekly using an open gas exchange system equipped with a leaf chamber fluorometer (Li-6400; LI-COR). Measurements were made on one recently fully expanded leaf on each plant. Ambient light level was sampled at the beginning of each measurement period and set to that level for the duration of the period. There was little variation in light levels between weeks within a specific experiment. Measurements were not taken on cloudy days, and all measurements were taken between 1000 and $1400 \mathrm{HR}$. Ambient air temperatures were used and chamber $\mathrm{CO}_{2}$ level was set at $400 \mu \mathrm{mol} \cdot \mathrm{mol}^{-1}$ for all measurements. Gas exchange was measured for all species except $P$. Xmexicali and L. angustifolia because leaves of these species were too small to fill the measuring chamber.

Plant tissue analyses. Leaf $\mathrm{Ca}$ and $\mathrm{Na}$ concentrations were determined for plants grown in the Spring and Summer 2004 experiments. Leaves were removed from dry shoots, and for each species the leaves from all replications of a given salinity treatment were combined and ground. One composite tissue sample for each species and salinity treatment was digested in a solution of nitric acid and peroxide (Jones and Case, 1990), and analyzed using inductively coupled plasma emission spectroscopy at the Utah State University Analytical Laboratory (Logan, Utah). The single replicate of tissue data precluded statistical analysis of these data. Results are provided only to suggest trends and possible explanations for salinity effects.

Medium salinity. Medium salinity was assessed at the end of each experiment. For 
each species grown in 2003, media samples were taken from the root zone of each plant and combined with all other samples from that specific salinity treatment. Samples were mixed thoroughly and analyzed as a saturated paste extract. For all other experiments, soluble salts were extracted from individual media samples taken from the root zone of each plant using the 2:1 dilution method. Electrical conductivity of each extract was determined using a portable EC meter (Extech Instruments, Waltham, Mass.).

Statistical analyses. Visual quality ratings, shoot and root dry weight, and gas exchange data were analyzed using analysis of variance for a mixed model. Only the final quality ratings were used in the analysis. Gas exchange $\left(\mathrm{P}_{\mathrm{n}}\right.$ and $\left.g_{\mathrm{s}}\right)$ declined during the experiments for most species when exposed to the salinity treatments (data not presented). Steady-state values were identified from the last measurement day that was significantly different from the prior measurement dates, and for which subsequent measurement dates were nonsignificant. For most species this was at the end of the experiment, and for a few species the date was 1 or 2 weeks before the end. All analyses were performed separately for each repetition of the experiments because of the variable environmental conditions in the greenhouse. Blocks were considered random effects, and salinity treatments were considered fixed effects. The SAS procedure PROC MIXED was used for all data analyses (version 9.1; SAS Institute, Cary, N.C.). Tukey's HSD test was used to separate means $(P \leq 0.05)$. Several of the $L$. Xsuperbum and $P$. palmeri plants were diseased by the end of the Spring 2004 and Spring 2003 experiments respectively. Data from diseased plants were omitted from statistical analysis. A visual quality rating of 0 was used in the statistical analysis for plants that had died as a result of the salinity treatments.

\section{Results and Discussion}

Of the eight species tested, $L . \times$ superbum and $M$. multiflora maintained the highest overall visual quality across salinity treatments (Fig. 1). This response was similar for both experiments, with light intensity and greenhouse temperature having little effect on plant response to salt treatments. Similarly, there were no statistical differences in visual quality of $L$. angustifolia at salinity levels $\leq 3000 \mathrm{mg} \cdot \mathrm{L}^{-1}$, with similar quality responses between experiments. About 25\% of the M. multiflora plants treated with saline water showed some pink discoloration on leaf margins and flower bracts, and leaves from plants in all salinity treatments were visibly thicker than those in the control group. Mirabilis multiflora plants developed some succulence when exposed to salinity, similar to what has been observed for several other dicotyledonous glycophytes exposed to $\mathrm{NaCl}$ (Jennings, 1976). Succulence may be linked with the ability of plants to dilute salts within their cells and thus tolerate high levels

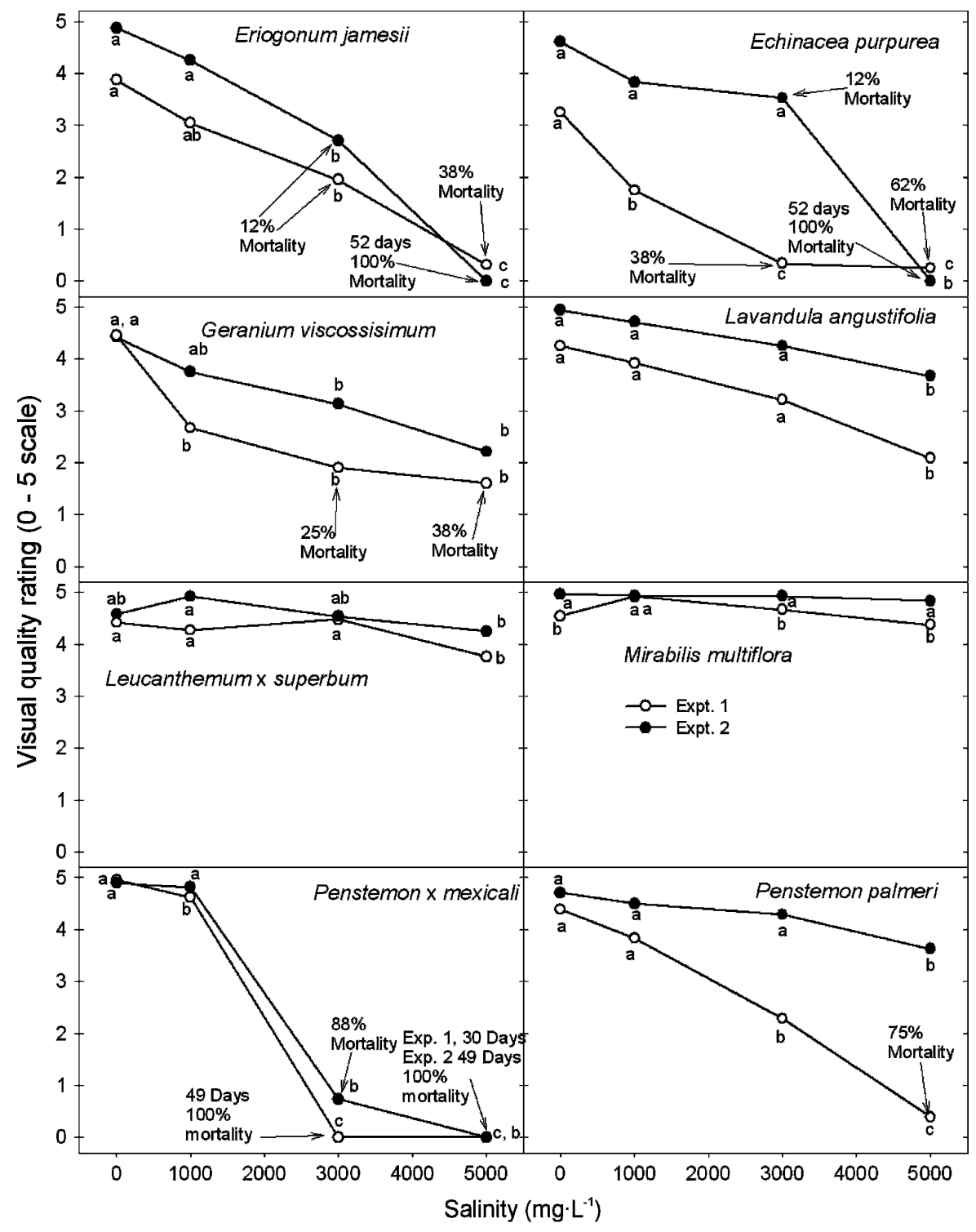

Fig. 1. Visual quality ratings ( 0 , dead plants; 1 , plants exhibiting severe leaf loss, burn, discoloration, or wilt; 5, plants exhibiting no leaf loss, burn, discoloration, or wilt) for each species across salinity treatments taken at the end of the experiments. Tukey's HSD test was used to separate means within an experiment $(P \leq 0.05)$.

of salinity (Munns, 2002). Leucanthemum ×superbum showed occasional minor tip burn at the highest salinity treatments, whereas L. angustifolia exhibited no visual symptoms in response to salinity treatments. No mortality was observed for $L$. ×superbum, M. multiflora, or L. angustifolia in any salinity treatment.

Geranium viscosissimum, $P$. palmeri, and E. purpurea showed intermediate visual quality responses to salt treatments, and responses varied with the time of the year the experiment was performed. Geranium viscosissimum had similar visual quality ratings among salinity treatments $\geq 1000$ $\mathrm{mg} \cdot \mathrm{L}^{-1}$ in both experiments. However, in Expt. 1 (Summer 2004), responses were more severe; severe leaf burn and chlorosis were present, and the plants experienced $25 \%$ and $38 \%$ mortality at salinity levels of 3000 $\mathrm{mg} \cdot \mathrm{L}^{-1}$ and $5000 \mathrm{mg} \cdot \mathrm{L}^{-1}$ respectively. Pen- stemon palmeri showed severe leaf burn and wilting in Expt. 1 (Spring 2003) when exposed to $\geq 3000 \mathrm{mg} \cdot \mathrm{L}^{-1}$ salinity, with $75 \%$ mortality as salinity increased to 5000 $\mathrm{mg} \cdot \mathrm{L}^{-1}$. Plants were less affected in Expt. 2 (Summer 2004), with similar visual ratings among the control, $1000-\mathrm{mg} \cdot \mathrm{L}^{-1}$, and 3000 $\mathrm{mg} \cdot \mathrm{L}^{-1}$ treatments. Visual quality of $E$. purpurea declined and mortality increased at lower salinity levels in Expt. 1 (Spring 2003) than in Expt. 2 (Spring 2004). Plants treated with $5000 \mathrm{mg} \cdot \mathrm{L}^{-1}$ salt showed $62 \%$ and $100 \%$ mortality in Expt. 1 (Spring 2003) and Expt. 2 (Spring 2004). Niu and Rodriquez (2006) also found that E. purpurea was relatively sensitive to a solution composed of $\mathrm{NaCl}, \mathrm{MgSO}_{4}$, and $\mathrm{CaCl}_{2}$, with a salinity level as low as $2 \mathrm{dS} \cdot \mathrm{m}^{-1}$.

The daily light integral (DLI) and temperature ranges for the experimental periods were 13.88 to $17.98 \mathrm{~mol} \cdot \mathrm{m}^{-2} \cdot \mathrm{d}^{-1}$ and 12 to 
$33{ }^{\circ} \mathrm{C}$ respectively, depending on the season (Table 1). The recommended minimum DLI for herbaceous perennials such as Achillea $\times$ millefolium, Gaura lindheimeri, and L. angustifolia is 15 to $20 \mathrm{~mol} \cdot \mathrm{m}^{-2} \cdot \mathrm{d}^{-1}$ when grown at average temperatures of $22{ }^{\circ} \mathrm{C}$ (Fausey et al., 2005). Light intensities and temperatures were not excessive, but did vary among the experiments and had an impact on the response of certain species to salinity. Results suggest that irrigation with saline water would lower the visual quality of G. viscosissimum, E. purpurea, and P. palmeri more during the warmer, summer months. Crop plants also respond differently to salinity when grown in high temperatures compared with lower temperatures (Ahi and Powers, 1938; Magistad et al., 1943), likely because of higher metabolic activity and transpiration rates with higher temperatures. More recently, 7 of 19 landscape plant species treated with sprinkler reuse water with a salinity level of $1.94 \mathrm{dS} \cdot \mathrm{m}^{-1}$ showed less visual damage when shaded than those without shade (Devitt et al., 2005). Fox et al. (2005) also noted that damage to landscape plants from treated effluent irrigation was worse during the warmest part of the summer than during cooler periods.

Penstemon $\times$ mexicali and E. jamesii were the most intolerant of the species tested based on visual quality, exhibiting sharp declines in quality ratings as salinity increased to 3000 and $5000 \mathrm{mg} \cdot \mathrm{L}^{-1}$ in both experiments (Fig. 1). Penstemon $\times$ mexicali also exhibited high mortality rates $(>85 \%)$ at the $\geq 3000-\mathrm{mg} \cdot \mathrm{L}^{-1}$ salinity treatments in both experiments. Severe marginal necrosis was evident on all salt-treated $E$. jamesii plants in both experiments, and $38 \%$ and $100 \%$ of the plants died during Expt. 1 (Spring 2003) and Expt. 2 (Spring 2004) respectively when treated with $5000 \mathrm{mg} \cdot \mathrm{L}^{-1}$ salt. Based on visual quality response and high mortality, these perennials would not be recommended for landscapes in which saline irrigation water is used.

Media EC for the Spring 2003 experiments was only slightly higher than the EC of the applied solution $\left(2.2,5.4\right.$, and $8.3 \mathrm{dS} \cdot \mathrm{m}^{-1}$ for the $1000-, 3000-$, and $5000-\mathrm{mg} \cdot \mathrm{L}^{-1}$ salinity treatments respectively). Leucanthemum ×superbum and M. multiflora irrigated with saline water had much higher root zone salinity than the other species in the study in at least one of the two experiments, but still maintained high visual quality. For example, with L. Xsuperbum in Expt. 2 (Fall 2004), media EC averaged 3.4, 8.2, and $9.8 \mathrm{dS} \cdot \mathrm{m}^{-1}$ for the $1000-, 3000-$, and $5000-\mathrm{mg} \cdot \mathrm{L}^{-1}$ salinity treatments respectively. For M. multiflora, in Expt. 1 (Summer 2004), media EC averaged 2.8, 7.5, and $10.1 \mathrm{dS} \cdot \mathrm{m}^{-1}$ for the $1000-$, $3000-$, and $5000-\mathrm{mg} \cdot \mathrm{L}^{-1}$ salinity treatments respectively, although media salinity levels were close to the applied salinity levels for Expt. 2 (Fall 2004). These relatively high media EC levels provide further evidence that these species are more salt tolerant than the others evaluated in this study.

Certain species showed similarities between plant visual quality ratings (Fig. 1) and root and shoot biomass responses to salinity (Fig. 2). For example, as salt levels increased there was a decrease in visual quality and biomass production of G. viscosissimum and $P$. ×mexicali. Leucanthemum $\times$ superbum, however, maintained high visual quality ratings but experienced a significant reduction in biomass with increasing salinity treatments in both experiments. In contrast, E. jamesii experienced relatively small (Expt. 1, Spring 2003) or no (Expt. 2, Spring 2004) declines in shoot biomass with increasing salinity, but visual quality ratings declined significantly, and mortality increased in both experiments as salinity increased to $\geq 3000$ $\mathrm{mg} \cdot \mathrm{L}^{-1}$. Niu and Rodriguez (2006) found similar results with Agastache cana, for which relatively few differences were found in biomass production among salinity treatments, but low visual quality ratings made the species unacceptable for the landscape. Results from our study suggest species vary in visual quality and biomass responses to salinity, with some able to maintain quality with declining biomass and others experiencing decreases in quality while maintaining biomass in response to increasing salinity. This is not surprising because visual quality, as defined here, is not directly related to plant size or other characteristics that may influence biomass at harvest.

Many of the species showed more similar trends between visual quality ratings and $P_{n}$ and $\mathrm{g}_{\mathrm{s}}$ (Figs. 1 and 3 ) than between biomass and $\mathrm{P}_{\mathrm{n}}$ and $\mathrm{g}_{\mathrm{s}}$ (Figs. 2 and 3). One exception was $M$. multiflora, which maintained high visual quality ratings throughout all treatments but showed a reduction in $\mathrm{P}_{\mathrm{n}}$ and $\mathrm{g}_{\mathrm{s}}$ at $\geq 3000 \mathrm{mg} \cdot \mathrm{L}^{-1}$. For L. Xsuperbum and M. multiflora, reductions in $\mathrm{P}_{\mathrm{n}}$ for salt-treated plants were generally less severe than reductions in $g_{\mathrm{s}}$. This has been observed for the halophytes Salicornia europaea ssp. rubra and Puccinellia nuttalliana grown under saline conditions (Guy and Reid, 1986; Guy et al., 1980). However, for sunflower, a less

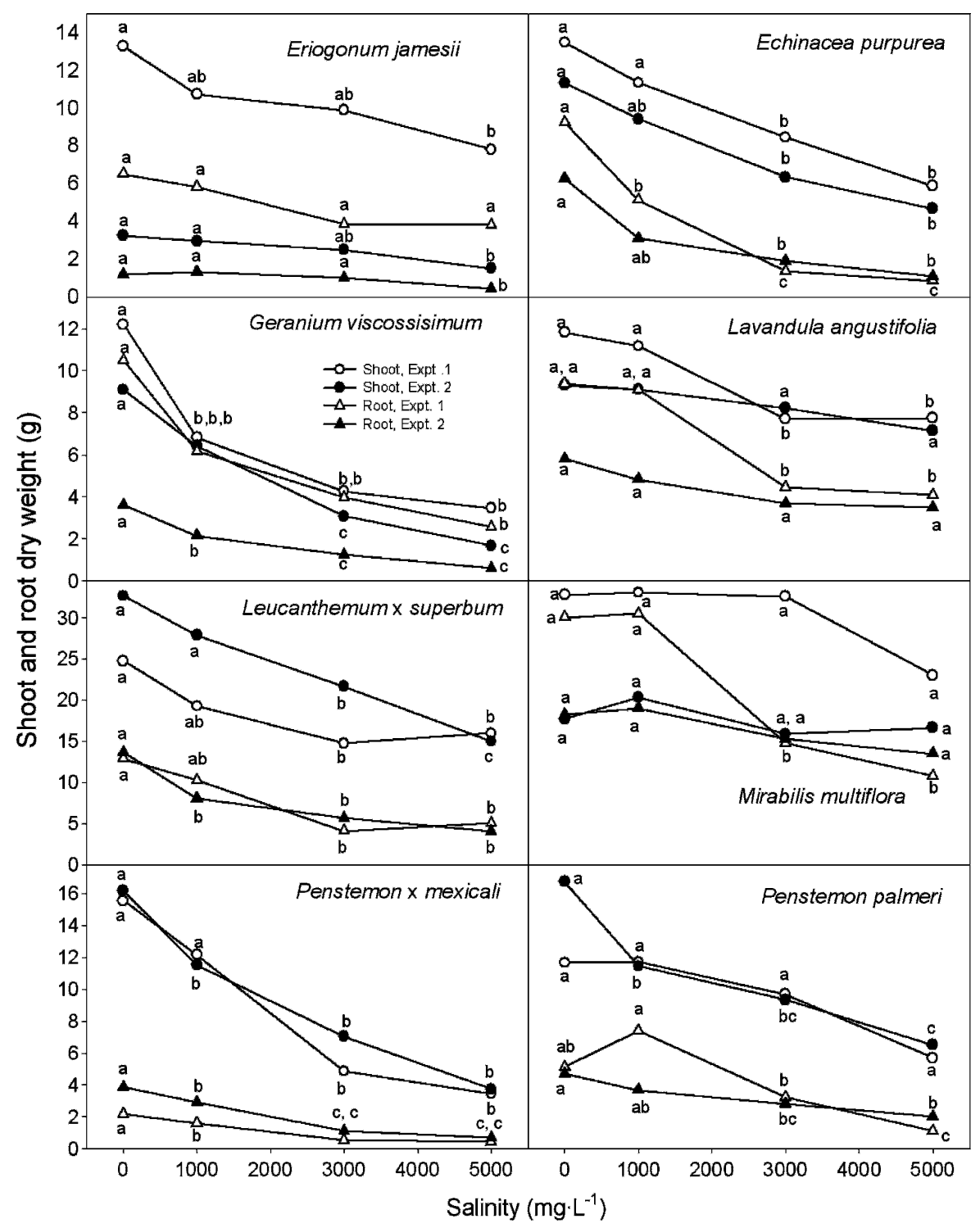

Fig. 2. Shoot and root dry weight at harvest for each species across salinity treatments. Tukey's HSD test was used to separate means within an experiment $(P \leq 0.05)$. 


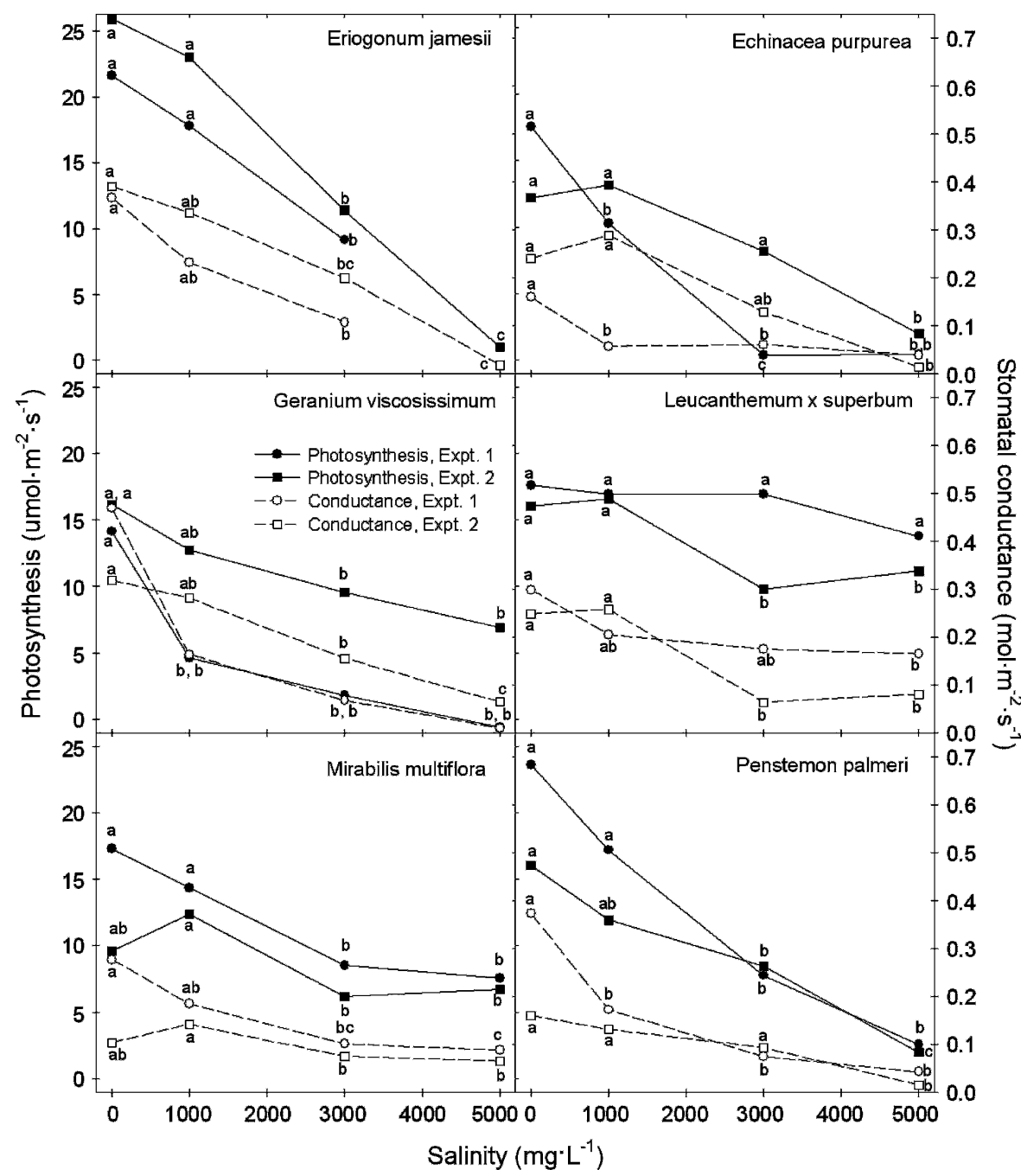

Fig 3. Photosynthesis $\left(P_{n}\right)$ and stomatal conductance $\left(g_{s}\right)$ for six of the species across salinity treatments for both experiments. Values in the figure are from measurements taken near the end of each experiment when steady-state conditions were reached for each species. Tukey's HSD test was used to separate means within an experiment $(P \leq 0.05)$.

salt-tolerant species, the opposite was observed (Rivelli et al., 2002). The mechanisms by which these species are able to maintain high $\mathrm{P}_{\mathrm{n}}$ while decreasing $g_{\mathrm{s}}$ have not been determined.

For most species, leaf $\mathrm{Na}$ and $\mathrm{Ca}$ levels increased with increasing salinity (data not presented). Sodium levels in the composite leaf samples of L. angustifolia irrigated with saline water were extremely high, especially for plants in the 3000- and 5000-mg. $\mathrm{L}^{-1}$ salinity treatments, which accumulated close to 4000 and $7700 \mathrm{mg} \cdot \mathrm{kg}^{-1} \mathrm{Na}$ respectively. The amount of $\mathrm{Na}$ in L. angustifolia leaves from plants in the 3000 - and 5000-mg. $\mathrm{L}^{-1}$ salinity treatments was nearly twice the amount in M. multiflora leaves from the same salinity treatments. Lavandula angustifolia was apparently able to tolerate extremely high levels of $\mathrm{Na}$ in leaf tissue while maintaining relatively high visual quality (Fig. 1) and dry matter (Fig. 2), suggesting that the species likely has mechanisms that protect cellular functions from salts. One possibility is that salts are compartmentalized within vacuoles. Interestingly, the three species deemed relatively salt tolerant based on visual quality response (L. angustifolia, $M$. multiflora, and L. Xsuperbum) accumulated the highest levels of $\mathrm{Na}$ in the leaves.

Some species are able to exclude salts from being absorbed, tolerating absorption by compartmentalizing salts in vacuoles, regulating movement of salts to shoots or exporting the salts away from the shoot, increasing succulence to dilute salts within the cell, excreting salts via salt glands or salt hairs, or dropping older leaves in which salts have accumulated (Greenway and Munns, 1980; Munns, 2002). Many of these species, including Texas sage (Leucophyllum frutescens) and iceplant (Delosperma), grow more vigorously in saline soils than in nonsaline soils (Francois and Clark, 1978). There was evidence of succulence with $M$. multiflora leaves. However, there was no indication that salinity enhanced the growth of any of the species used in this study.

Sodium is likely particularly toxic to E. purpurea and $P$. Xmexicali, because the plants apparently took up very little before death occurred, and visual symptoms of toxicity (marginal chlorosis and necrosis) were similar to those seen for other plants experiencing $\mathrm{Na}$ toxicity (Marschner, 1995). Studies by Bernstein et al. (1975) suggested accumulation of $\mathrm{Cl}$ or $\mathrm{Na}$ in leaves of selected ornamental shrubs and groundcovers might also interfere with stomatal closure and cause excessive water loss.

In summary, salt-sensitive plant species exhibited visual responses to salinity such as discoloration, wilt, and leaf burn that, for some species, were not consistent with dry matter responses. Aesthetic factors or visual appearance are more important than yield of ornamental plants, so salt sensitivity can limit the use of certain plants that might otherwise produce biomass. Other studies with herbaceous perennials have also emphasized the importance of visual quality for expressing relative salt tolerance and acceptability of species for landscape use (Fox et al., 2005; Niu and Rodriguez, 2006). The knowledge and potential use of herbaceous perennials tolerant of higher salinity situations would be valuable information for the landscaping industry. Based on our study, L. Xsuperbum, M. multiflora, and L. angustifolia would be considered relatively tolerant of salinity treatments up to $5000 \mathrm{mg} \cdot \mathrm{L}^{-1}$ as evidenced by survival and visual quality, while $G$. viscosissimum, P. palmeri, and E. purpurea would be considered intermediate in tolerance, with lower visual quality experienced during periods of high temperature and light levels. Eriogonum jamesii and $P$. ×mexicali were relatively intolerant of salinity $\geq 3000$ $\mathrm{mg} \cdot \mathrm{L}^{-1}$. Because three of the species in our study with relatively high ( $M$. multiflora) to moderate (G. viscosissimum and $P$. palmeri) salinity tolerance are IMW native species, the IMW may be a potential source for other salttolerant species.

\section{Literature Cited}

Ahi, S.M. and W.L. Powers. 1938. Salt tolerance of plants at various temperatures. Plant Physiol. 13:767-789.

Bernstein, L. 1975. Effects of salinity and sodicity on plant growth. Ann. Rev. Phytopathol. 13: 295-312.

Deeter, L.M. 2001. Sodium chloride tolerance of selected herbaceous perennials and the effects of sodium chloride on osmotic adjustment and ionic uptake in three species of herbaceous perennials. Ohio State Univ., Columbus, PhD Diss.

Devitt, D.A., R.L. Morris, L.K. Fenstermaker, M. Baghzouz, and D.S. Neuman. 2005. Foliar damage and flower production of landscape plants sprinkle irrigated with reuse water. HortScience 40:1871-1878.

Fausey, B.A., R.D. Heins, and A.C. Cameron. 2005. Daily light integral affects flowering and quality of greenhouse-grown Achillea, Gaura, and Lavandula. HortScience 40:114 118.

Fox, L.J., N. Grose, B.L. Appleton, and S.J. Donohue. 2005. Evaluation of treated effluent as an irrigation source for landscape plants. J. Environ. Hort. 23:174-178. 
Francois, L.E. and R.A. Clark. 1978. Salt tolerance of ornamental shrubs, trees and iceplant. J. Amer. Soc. Hort. Sci. 103:280-283.

Glenn, E.P. and J. Brown. 1998. Effects of soil salt levels on the growth and water use efficiency of Atriplex canescens (Chenopodiaceae) varieties in drying soil. Amer. J. Bot. 85:10-16.

Greenway, H. and R. Munns. 1980. Mechanisms of salt tolerance in nonhalophytes. Annu. Rev. Plant Physiol. 31:149-190.

Guy, R. and D. Reid. 1986. Photosynthesis and the influence of $\mathrm{CO}_{2}$-enrichment on delta $13 \mathrm{C}$ values in a $\mathrm{C}_{3}$ halophyte. Plant Cell Environ. 9:65-72.

Guy, R., D. Reid, and H. Krause. 1980. Shifts in carbon isotope ratios of two $\mathrm{C}_{3}$ halophytes under natural and artificial conditions. Oecologia 44:241-247.

James, D.W. and J.J. Jurinak. 1986. Irrigation resources in Utah: Water quality versus soil salinity, soil fertility and the environment. Res. Bul. 514. Utah Agr. Res. Sta., Logan, Utah.

Jennings, D.H. 1976. The effect of sodium chloride on higher plants. Biol. Rev. 51:453-486.

Jones, B.R. and V.W. Case. 1990. Sampling, handling and analyzing plant tissue samples, p. 389-427. In: R.L. Westerman (ed.). Soil testing and plant analysis. 3rd ed. Madison, Wisc., Soil Sci. Soc. of America, book ser. no. 3.
Kerstiens, G., W. Tych, M.F. Robinson, and T.A. Mansfield. 2002. Sodium-related partial stomatal closure and salt tolerance of Aster tripolium. New Phytol. 153:509-515.

Kjelgren, R., L. Rupp, and D. Kilgren. 2000. Water conservation in urban landscapes. HortScience 35:1037-1043.

Lindsey, P., M.A. Harivandi, and G. Setka. 1998. Recycled landscape irrigation water and ornamental plant compatibility study. 18 Mar. 2004. <http://ucce.ucdavis.edu/freeform/slosson/ documents/1995-19982110.pdf $>$.

Maas, E.V. and S.R. Grattan. 1999. Crop yields as affected by salinity, p. 55-108. In: R.W. Skaggs and J. van Schilfgaarde (eds.). Agricultural drainage. Agron. Monogr. 38. Amer. Soc. Agron., Madison, Wisc.

Magistad, O.C., A.D. Ayers, C.H. Wadleigh, and H.F. Gauch. 1943. Effect of salt concentration, kind of salt, and climate on plant growth in sand cultures. Plant Physiol. 18:151-166.

Marschner, H. 1995. Mineral nutrition of higher plants. 2nd ed. Academic Press, San Diego, Calif.

Mee, W., J. Barnes, R. Kjelgren, R. Sutton, T. Cerny, and C. Johnson. 2003. Waterwise: Native plants for intermountain landscapes. Utah State University Press, Logan, Utah.
Munns, R. 2002. Comparative physiology of salt and water stress. Plant Cell Environ. 25:239250.

Niu, G. and D.S. Rodriguez. 2006. Relative salt tolerance of five herbaceous perennials. HortScience 41:1493-1497.

Phillips, E. and C.C. Burrell. 1993. Illustrated encyclopedia of perennials. Rodale Press, Emmaus, $\mathrm{Pa}$.

Rivelli, A.R., S. Lovelli, and M. Perniola. 2002. Effects of salinity on gas exchange, water relations and growth of sunflower (Helianthus annuus). Funct. Plant Biol. 29:1405-1415.

Simini, M. and I.A. Leone. 1986. The response of dormant Norway and sugar maples to simulated deicing salt spray. J. Arboriculture 12:1-5.

Upson, T. and S. Andrews. 2004. The genus Lavandula. Timber Press, Portland, Ore.

Wang, Y. and N. Nii. 2000. Changes in chlorophyll, ribulose biphosphate carboxylaseoxygenase, glycine betaine content, photosynthesis and transpiration in Amaranthus tricolor leaves during salt stress. J. Hort. Sci. Biotechnol. 75:623-627.

Wu, L., X. Guo, and A. Harivandi. 2001. Salt tolerance and salt accumulation of landscape plants irrigated by sprinkler and drip irrigation systems. J. Plant Nutr. 24:1473-1490. 